Jurnal Konstruksi Hukum | ISSN: 2746-5055

Vol. 2, No. 2, Mei 2021, Hal. 390-395| Tersedia online di

https://www.ejournal.warmadewa.ac.id/index.php/jukonhum

DOI: https://doi.org/10.22225/jkh.2.2.3261.390-395

\title{
SANKSI HUKUM BAGI PASIEN TIDAK JUJUR TERINFEKSI CORONA VIRUS DISEASE 2019
}

\author{
Gede Dana Semara Putra, I Nyoman Putu Budiartha, I Made Minggu Widyantara \\ Fakultas Hukum Universitas Warmadewa, Denpasar-Bali, Indonesia \\ danasemaraputra@gmail.com, budiarthaputu59@gmail.com, mademinggu2@gmail.com
}

\begin{abstract}
Abstrak
Pemerintah Indonesia mengeluarkan Keppres No. 11 Tahun 2020 tentang Kedaruratan Kesehatan Masyarakat sebagai peringatan serius ancaman Covid-19. Penyampaian informasi tidak jujur dari pasien terduga terinfeksi Covid-19 merupakan tindakan menghalangi penanggulangan wabah yang mengancam jiwa orang di sekitamya, termasuk penularan kepada tenaga kesehatan yang merawatnya. Penelitian ini dirumuskan untuk mengetahui pengaturan sanksi terhadap pasien Covid 19 yang tidak jujur mengenai kondisi kesehatannya, dan untuk mengetahui upaya yang dilakukan pemerintah dalam memberikan perlindungan kepada tenaga kesehatan dalam penanganan pasien covid-19. Metode penelitian yang digunakan dalam pelaksanaan penelitian ini adalah penelitian hukum normatif dengan pendekatan konsep perundang-undangan dan pendapat para ahli mengenai hukum. Hasil penelitian menunjukkan bahwa penerapan sanksi tegas kepada tindakan penghalangan penanggulangan wabah dapat berakibat pada hukuman pidana ayng di dasari oleh undang-undang No. 4 Tahun 1984 tentang Wabah Penyakit Menular. Adapun upaya yang dilakukan pemerintah guna memberikan perlindungan kepada tenaga kesehatan dari ancaman Covid-19 diberikan secara preventif maupun represif. Berdasarkan hasil penelitian tersebut, dapat disimpulkan bahwa pasien yang tidak jujur mengenai kondisi kesehatannya yang sudah terinfeksi covid-19 dapat diberi hukuman pidana karena tindakan tersebut merupakan hal yang menghalangi pemerintah dalam menanggulangi wabah penyakit menular yang sedang melanda masyarakat, kemudian pemerintah juga telah memberikan perlindungan terhadap para tenaga kesehatan yang menangani pasien terinfeksi covid-19 secara preventif dan represif.
\end{abstract}

Kata kunci: Corona virus disease 2019; Pasien tidak jujur; Sanksi hukum.

\begin{abstract}
The Indonesian government issued Presidential Decree No. 11 of 2020 concerning Public Health Emergencies as a serious warning of the threat of Covid-19. The delivery of dishonest information from a patient suspected of being infected with Covid-19 is an action to prevent the response to an outbreak that threatens the lives of people around him, including transmission to health workers who care for him. This study was formulated to figure out the legal sanctions for Covid 19 patients who were dishonest about their health conditions, and to find out the efforts made by the government in providing protection to health workers in handling Covid-19 patients. The research method used in the implementation of this research is normative legal research with an approach to the concept of legislation and the opinions of experts regarding to the law. The results showed that the application of strict sanctions to obstruction of the epidemic prevention measures could result in criminal penalties based on Law No. 4 of 1984 concerning Outbreaks of Infectious Diseases. As for the efforts made by the government to provide protection to health workers from the threat of Covid-19, it is given both preventively and repressively. Based on the results of this study, it can be concluded that patients who are not honest about their health conditions who have been infected with Covid-19 can be given a criminal penalty because this action is assumed as the way to prevent the government in overcoming the epidemic of infectious diseases that are currently hitting the community, then the government has also provided protection for health workers who treat patients infected with Covid-19 in a preventive and repressive manner.
\end{abstract}

Keywords: Coronavirus disease 2019; Dishonest patient; Legal sanctions.

\section{PENDAHULUAN}

Pandemi virus Corona yang melanda hampir seluruh dunia, berawal pertama kali di negara China tepatnya di kota Wuhan. Penyebaran virus corona terjadi sangat cepat melalui udara dan menyerang organ vital manusia yaitu saluran pernafasan. Virus Corona yang menjadi pandemi pada akhir tahun 2019 ini dinamakan Covid-19. Peningkatan jumlah korban meninggal dan perluasan wilayah terdampak Corona menyebabkan berbagai negara membuat kebijakan terhadap warga negaranya, tak terkecuali Indonesia dengan menetapkan pandemi Covid-19 sebagai kedaruratan kesehatan melalui 
penetapan Keppres No. 11 Tahun 2020 didasarkan pada undang-undang Kekarantinaan Kesehatan No. 6 tahun 2018. Besarnya ancarnan kesehatan yang mengancarn seluruh lapisan masyarakat membuat Pemerintah Indonesia dengan cepat dan tegas menyatakan panderni ini sebagai kedaruratan kesehatan serta merespon kejadian luar biasa ini dengan pelaksanaan Pembatasan Sosial Berskala Besar (PSBB). Beberapa daerah juga mengeluarkan surat edaran mengenai pembatasan gerak sosial masyarakat serta mengkarantina wilayahnya dari segala aktivitas antar wilayah.

Berdasarkan Keppres No. 7 tahun 2020, pemerintah Indonesia membentuk Gugus Tugas penanganan Covid-19 melalui situs online www.covid19.go.id sebagai pusat informasi resmi covid-19 yang cepat, terpercaya, dan akurat. Segala berita terkini terkait penanggulangan covid-19 dapat diakses melalui situs online itu termasuk protokol kesehatan yang wajib dipatuhi masyarakat selama pandemi. Protokol kesehatan yang wajib dipatuhi oleh seluruh masyarakat diantaranya, rajin mencuci tangan dengan sabun di air mengalir atau selalu membawa cairan pencuci tangan berbasis alkohol. Kemudian wajib menggunakan masker saat keluar rumah, serta menjaga jarak minimal 1 (satu) meter dengan orang lain yang biasa disebut physical distancing. Melalui protokol kesehatan, masyarakat diajak untuk berperilaku hidup bersih dalam kesehariannya guna menekan penyebaran covid-19. Kebijakan lain yang diterbitkan pemerintah Indonesia terkait pandemi yairu pembatasan sosial berskala besar dan stabilitas sistem keuangan negara sebagai kegentingan yang memaksa diterbitkannya Perppu No. 1 Tahun 2020. Dasar konstitusional dari diterbitkannya produk hukum bernama Perppu adalah Pasal 22 ayat (1) UUD NRI 1945, berbunyi: "Dalam hal ihwal kegentingan yang memaksa, Presiden berhak menetapkan peraturan pemerintah sebagai pengganti undangundang".

Kewenangan presiden atas pembenrukan Perppu tidak serta merta digunakan bilamana presiden berkehendak, tetapi atas dasar telah terpenuhinya prasyarat kegentingan yang memaksa. Tiga (3) syarat penetapan Perppu, yaitu; adanya kebutuhan yang mendesak untuk bertindak (reasonablenecessity); terdapat kegentingan waktu; dan tidak tersedia alternatif lain atau penalaran yang wajar (beyond reasonable doubt) alternatif lain diperkirakan tidak dapat mengatasi keadaan, sehingga penetapan Perppu merupakan satu-satunya cara untuk mengatasi keadaan (Asshiddiqie, 2007). Unsur-unsur kegentingan yang memaksa sehingga diterbitkannya Perppu diantaranya akibat terjadi permasalahan hukum yang harus diselesaikan secara cepat, serta adanya kekosongan hukum yang tidak dapat diatasi secara prosedur biasa. Kekosongan hukum yang terjadi hingga diterbitkannya Perppu mengenai stabilitas sistem keuangan negara adalah dalam hal pengaturan pembiayaan dan peningkatan belanja negara. Pengaturan pembiayaan dan peningkatan belanja negara diperlukan sebagai upaya pemerintah dalam penyelamatan perekonomian nasional. Atas permasaJahan kesehatan dan perekonomian nasional yang kian memburuk secara cepat, maka pemerintah meJakukan tindakan antisipasi dalam rangka menjaga stabilitas sektor keuangan melalui penerbitan Perppu. Pembatasan Sosial Berskala Besar (PSBB) memberlakukan segala aktivitas masyarakat dilakukan di rumah melalui internet, termasuk bekerja dan bersekolah dari rumah. amun pembatasan tersebut tidak berlaku bagi para tenaga kesehatan karena pelayanan kepada pasien rawat inap hanya dapat dilakukan secara langsung. Tenaga kesehatan merupakan garda depan penanganan pasien covid-19 sehingga mereka menjadi kelompok rentan untuk tertular (Pesulima \& Hetharie, 2020). Untuk itulah perlindungan terhadap tenaga kesehatan diperlukan guna tetap dapat memberikan pelayanan kepada pasien di tengah situasi darurat saat ini.

Dampak kesehatan serius dari penularan Covid-19 dapat menyebabkan kematian membuat masyarakat merasa khawatir tertular virus Corona. Kekhawatiran tersebut terlihat dari pengucilan kepada penderita covid 19 beserta keluarganya. Tidak semua penderita covid-19 memperlihatkan gejala penyakit ini secara nyata, sehingga bagi orang yang memiliki riwayat perjalanan ke zona penularan corona maka ia wajib diperiksa kesehatannya guna menekan penularan penyakit. Dampak psikologis berupa pengucilan kepada penderita covid-19 beserta keluarganya yang terjadi di tengah masyarakat membuat sebagian orang memilih unruk tidak jujur atas kondisi kesehatan mereka. Seluruh dimensi kehidupan bermasyarakat dan bernegara di Indonesia harus berdasarkan aturan hukum guna mewujudkan tujuan hukum yang adil dengan memperhatikan hak dan kewajiban setiap warga Negara (Asyiah, 2016). Selain mengatur hak dan kewajiban warga negara, hukum juga berfungsi sebagai instrumen perlindungan bagi subjek hukum. Pelanggaran terhadap aturan hukum dapat menimbulkan reaksi berupa tindakan disorderatau ketidakreraruran hukum dalam masyarakat. Setiap pelanggaran atas aturan hukum mengakibatkan dikenakannya sanksi sebagai alat pemaksa 
diberlakukannya peraruran tersebut. Sanksi menurut ketentuan undang-undang terbagi atas sanksi perdata, sanksi administratif, dan sanksi pidana. Sanksi pidana bersifat lebih tajam daripada sanksi lainnya karena adanya penderitaan yang sengaja ditimpakan kepada pelanggar yang melawan hukum. Penegakan hukum wajib mernperhatikan unsur kepastian hukum, kemanfaatan, dan keadilan secara seimbang (Mertokusumo, 1999). Undang-undang dibuat dengan jelas dan logis agar tidak menimbulkan multitafsir yang mengakibatkan konflik norma. Selain itu hukum juga memberikan kepada setiap orang atas apa yang menjadi haknya berdampingan dengan kewajibannya. Keputusan sanksi ditetapkan agar bermanfaat bagi rakyat banyak. Hak pasien adalah memperoleh pelayanan yang baik dari tenaga kesehatan sehubungan dengan penyakit yang dideritanya (Lamintang, 2010). Sejalan dengan itu, kewajiban memberikan informasi mengenai kondisi kesehatan dan riwayat perjalanan seseorang terduga terinfeksi covid-19 selama wabah berl angsung harus disampaikan sejujumya agar penanganan pengobatan dapat dicapai maksimal. Ketidakjujuran berkaitan keterangan yang disampaikan saat kejadian luar biasa padahal orang tersebut patut diduga terinfeksi covid-19 dapat dikategorikan sebagai tindakan menghalangi penanganan wabah sehingga berdasarkan undangundang dapat dipidana.

Berdasarkan uraian di atas, maka penelitian dirumuskan untuk mengetahui pengaturan sanksi terhadap pasien Covid 19 yang tidak jujur mengenai kondisi kesehatannya, dan untuk mengetahui upaya yang dilakukan pemerintah dalam memberikan perlindungan kepada tenaga kesehatan dalam penanganan pasien covid-19.

\section{METODE PENELITIAN}

Untuk memperoleh, mengumpulkan, merumuskan dan menganalisa bahan hukum ilmiah ini memerlukan metode penelitian sistematis dan terarah serta konsisten. Tipe penelitian yang digunakan dalam penelitian ini adalah tipe penelitian hukum normatif yaitu jenis penelitian penulisan melalui studi kepustakaan dengan mengkaji bahan-bahan hukum untuk menemukan aturan hukum dan prinsip-prinsip hukum mengenai sanksi hukum (Fajar \& Yulianto, 2009) bagi pasien tidak jujur terinfeksi corona vims disease 2019 (Covid-19). Pendekatan yang digunakan dalam pemecahan masalah adalah pendekatan perundang-undangan (statute approach) yaitu pendekatan yang dilakukan dengan menelaah semua peraturan perundang-undangan yang bersangkutan dengan permasalahan yang sedang dihadapi. Adapun pendekatan konseptual yang juga digunakan (conceptual approach) merupakan pendekatan yang beranjak dari pandangan-pandangan dan doktrin-doktrin yang berkembang dalam ilmu hukum. Digunakan juga pendekatan kasus yang berhubungan dengan permasalahan dalam penelitian ini. Sumber bahan hukum dalam penelitian ini adalah bahan hukum primer yaitu bahan hukum yang mempunyai kekuatan yang mengikat secara umum (perundangundangan) atau mempunyai kekuatan mengikat bagi pihak yang berkepentingan. Bahan hukum sekunder, memberikan penjelasan mengenai bahan hukum primer, misalnya literatur mengenai pandemi Covid-19, serta karangan ilmiah dari para ahli hukum pidana yang dapat diakses melalui buku-buku dan media internet. Teknik pengumpulan bahan hukum yang digunakan adalah teknik dokumentasi yang dilaksanakan dengan cara menginventarisasi bahan-bahan hukum baik berupa peraturan perundang-undangan, literatur-literatur, maupun bahan hukum lainnya yang berkaitan dengan permasalahan dalam penelitian ini.

\section{HASIL DAN PEMBAHASAN}

\section{Pengaturan Sanksi terhadap Pasien Covid 19 yang Tidak Jujur Mengenai Kondisi Kesehatannya}

Pada hakikatnya, hukum bersifat mengatur, memaksakan segala aturannya dan memberikan sanksi bagi pelanggar hukum. Melanggar aturan hukum dikatakan sebagai tindakan melawan hukum karena pelanggaran undang-undang yang merugikan masyarakat. Untuk itu penegakan hukum harus dilakukan dengan pemberian sanksi demi terwujudnya ketertiban hukum dalam upaya memberikan perlindungan kepada masyarakat. Penegakan hukum merupakan kegiatan menyerasikan hubungan nilai-nilai dalam aturan hukum kemudian merealisasikannya dalam sikap dan tindakan demi terciptanya kedamaian dalam bermasyarakat. Tiga unsur dalam penegakan hukum harus memperhatikan kepastian hukum, kemanfaatan, dan keadilan. ketiga unsur tersebut harus diusahakan untuk dilaksanakan secara proporsional dan seimbang. Bila keseimbangan itu tidak mungkin dilaksanakan maka keadilan haru diprioritaskan, kemudian kemanfaatan hingga akhirnya pada 
kepastian hukum. Keadilan dalam kaitannya dengan hubungan antar manusia adalah mengenai hak dan kewajiban yang dilaksanakan secara proporsional. Asas keadilan dan kepastian hukum juga disertai dengan asas kemanfaatan guna menjaga kestabilan di dalam masyarakat. Sebagai bentuk kepastian hukumnya, maka penerapan sanksi yang diberlakukan bagi pelanggar aturan hukum merupakan tindakan nyatanya. Bentuk upaya pemerintah dalam memberikan perlindungan kepada masyarakat dapat berupa meningkatkan derajat kesehatan masyarakat melalui pelayanan kesehatan sesuai nilai-nilai hak asasi manusia.

Pemenuhan hak kesehatan kepada masyarakat juga memerlukan peran dari masyarakat iru sendiri, seperti misalnya mengikuti anjuran pemerintah dalam upaya menekan laju penyebaran penyakit. Membanru tenaga kesehatan dengan memberikan keterangan yang benar mengenai riwayat penyakitnya agar pengobatan dapat diberikan dengan tepat. Dalam pelayanan kesehatan tidak terlepas dari hubungan antara dokter dengan pasien dilihat dari adanya transaksi terapeutik yang melahirkan hak dan kewajiban bagi kedua belah pihak. Transaksi terapeutik bertujuan untuk menyembuhkan dan mencegah penyakit, meringankan penderitaan, serta untuk mendampingi pasien (Komalawati, 2002). Pelayanan pada dasarnya dikatakan sebagai usaha untuk membantu menyiapkan segala hal yang dibutuhkan orang lain hingga mencapai keinginan yang diharapkan oleh konsumen. Dalam transaksi terapeutik, konsumen adalah orang sakit (pasien) yang meminta pengobatan kepada dokter. Para pihak dalam transaksi terapeutik memiliki posisi sederajat sehingga menempatkan keduanya pada kedudukan tanggung gugat yang sama. Tindakan terapeutik yang dilakukan tenaga kesehatan selalu berdasarkan pedoman pelaksanaan tugas sesuai fungsi juga sebagai alat penilaian kinerja bagi instansi pemerintah maupun non pemerintah. Transaksi terapeutik menciptakan perjanjian antara tenaga kesehatan dengan pasien yang diatur di dalam hukum perjanjian utamanya pasal $1320 \mathrm{BW}$ terkait syarat sah perjanjian.

Syarat kesepakatan dalam tran aksi terapeutik dapat dilihat dari ditandatanganinya perjanjian antara pasien atau penanggungjawab pasien dalam menerima pengobatan atau pasien tersebut telah setuju menerima pelayanan kesehatan dari dokter. Syarat kecakapan juga terlihat dari usia pasien atau usia penanggungjawab pasien yang menandatangani perjanjian, yaitu telah berusia genap 21 tahun atau lebih. Kemudian syarat hal tertentu merupakan bahwa pengobatan yang diberikan adalah telah sesuai dengan standar pelayanan kesehatan dan tidak bertentangan dengan ketentuan hukum yang berlaku. Sebagai syarat keempat yaitu sebab yang halal, bahwa pengobatan yang diberikan oleh dokter atau rumah sakit tidak bertentangan dengan undang-undang kesehatan atau juga tidak melanggar kode etik kedokteran. Perjanjian tersebut menimbulkan akibat hukum dimana perjanjian yang dibuat iru berlaku sebagai undang-undang bagi para pihak. Perjanjian tidak dapat ditarik kembali tanpa kesepakatan kedua belah pihak kecuali ada alasan lain yang diperbolehkan oleh undang-undang. Asas itikad baik selalu di junjung dalam pembuatan perjanjian. Penerapan asas itikad baik dalam perjanjian terapeutik dapat dilihat dari hak dan kewajiban yang dilaksanakan secara timbal balik. Seperti misalnya, kejujuran pasien dalam memberikan informasi tentang gejala penyakitnya serta pemberian pelayanan medik dari tenaga medis yang didasarkan pada keahlian dan keterampilan mereka. Pada situasi wabah covid-19, ketidakjujuran pasien atas informasi kesehatannya dapat mengancam nyawa petugas medis dan orang-orang di sekitar pasien sehingga dianggap menghalangi pelaksanaan penanggulangan wabah (Aurelia, 2017). Atas tindakan tersebut pasien dapat diancam pidana penjara selama-lamanya satu tahun dan/atau denda setinggi-tingginya satu juta berdasarkan Pasal 14 ayat (1) dan (2) UU No. 4/1984 tentang wabah penyakit menular.

\section{Upaya Pemerintah dalam Memberikan Perlindungan kepada Tenaga Kesehatan dalam Penanganan Pasien Covid-19}

Tenaga kesehatan merniliki faktor resiko yang sangat tinggi untuk tertular Covid-19, Oleh sebab itu diperlukan upaya untuk meningkatkan kesadaran semua pihak tentang pentingnya keselamatan tenaga kesehatan. Tenaga kesehatan berdasarkan peraruran perundang-undangan berhak unruk mendapatkan hak lain diluar hak imperatif dari pemerintah (Purbacaraka \& Soekanto, 1979). Hak lain dapat berupa hak fakultatif yang bersifat sebagai pelengkap, seperti misalnya pemberian Alat Pelindung Diri (APD) serta vitamin dan waktu istirahat bagi tenaga kesehatan selama pandemi. Pemerintah berupaya memberikan perlindungan hukum kepada tenaga kesehatan selarna wabah berlangsung. Perlindungan hukum merupakan gambaran dari bekerjanya fungsi hukum untuk mewujudkan tujuan hukum (keadilan, kemanfaatan, dan kepastian hukum). Perlindungan hukum diberikan kepada subjek hukum 
sesuai aruran hukum yang bersifat preventif maupun represif, baik secara terrulis maupun tidak tertulis demi penegakan peraruran hukum.

Menindaklanjuti tanggung jawab negara kepada warga negaranya pada situasi pandemi Covid19, maka Pemerintah melakukan tindakan perlindungan hukum preventif dengan mengeluarkan kebijakan terkait Penanganan Covid-19, diantaranya; Keppres Nomor 11 Tahun 2020 tentang Penetapan Kedaruratan Kesehatan Masyarakat Coronavirus Disease 2019 (Covid-19), dan PP No. 21 tahun 2020 tentang Pembatasan Sosial Berskala Besar Dalam Rangka Percepatan Penanganan Corona virus Disease 2019 (Covid-19). Perlindungan hukum preventif diberikan oleh Pemerintah dengan tujuan untuk mencegah sebelum terjadinya pelanggaran serta memberikan rambu-rambu atau batasanbatasan dalam melakukan kewajiban. Keselamatan tenaga kesehatan selama bertugas mendapat perhatian ekstra rnelalui pemberian Alat Pelindung Diri (APD), pemberian vitamin, makanan dan air mineral. Penerapan physical distancing sebagai salah satu cara meminimalisir penularan secara langsung di samping penyediaan hand sanitizer di lingkungan rumah sakit serta keharusan menggunakan masker bagi pasien yang datang ke rumah sakit untuk mengurangi tingkat penularan lewat udara saat pasien batuk atau bersin.

Bila telah terjadi pelanggaran terhadap upaya perlindungan hukum preventif maka secara tegas berlaku perlindungan akhir berupa sanksi sebagai bentuk perlindungan hukum secara represif. Perlindungan hukum represif merupakan langkah yang dilakukan apabila suatu kejadian yang berakibat hukum itu telah terjadi (Sukendar \& Santoso, 2019). Perlindungan hukum ini diberikan untuk menyelesaikan sengketa suatu pelanggaran yang telah terjadi dengan tetap mengindahkan perlindungan terhadap hak asasi manusia. Sanksi merniliki tiga komponen dengan perannya masingmasing, yaitu sebagai alat pemulih keadaan, sebagai pemenuh keadaan, dan hukuman. Terhadap perbuatan seseorang yang merugikan orang lain dan rnelanggar ketentuan hukum digolongkan kedalam perbuatan melawan hukum. Himbauan pemerintah tentang kewajiban rnelaksanakan protokol kesehatan bagi masyarakat kerap kali dilanggar sehingga pemerintah daerah menerapkan sanksi berupa sanksi denda dan sanksi sosial, seperti membersihkan fasilitas umum atau membayar sejumlah uang karena tidak menggunakan masker saat berinteraksi dengan orang lain.

Pemerintah daerah di beberapa provinsi di Indonesia telah melaksanakan Pembatasan Sosial Berskala Besar (PSBB) dengan menerbitkan Peraturan Gubemur, diantaranya Pergub DKI Jakarta No. 41/2020 tentang Pengenaan Sanksi Terhadap Pelanggar Pelaksanaan PSBB dalam Penanganan Covid19. Kemudian ada Pergub Provinsi Bali No. 46 tahun 2020 tentang Penerapan Disiplin Dan Penegakan Hukum Protokol Kesehatan Sebagai Upaya Pencegahan Dan Pengendalian Corona virus Disease 2019 dalam Tatanan Kehidupan Era Baru. Peraturan-peraturan gubernur tersebut menyertakan sanksi yang ditujukan kepada perorangan, pelaku usaha, pengelola usaha, penyelenggara, penanggung jawab tempat dan fasilitas urnum yang terbukti melanggar protokol kesehatan maupun melanggar PSBB. Jenis sanksi bagi pelanggar himbauan pemerintah ataupun protokol kesehatan, seperti sanksi sosial berupa publikasi di media massa bagi perusahaan yang bandel tidak menerapkan protokol kesehatan di tempat usahanya. Kemudian adanya sanksi administratif berupa teguran maupun pemberhentian usaha sementara, serta sanksi denda. Bila pelanggar tidak kooperatif, maka diancam dengan sanksi pidana berdasarkan ketentuan pasal $93 \mathrm{UU}$ Nomor 6 tahun 2018 tentang Kekarantinaan Kesehatan.

\section{SIMPULAN DAN SARAN}

\section{Simpulan}

Penegakan hukum identik dengan pemberian sanksi bagi para pelanggamya serta merupakan syarat terwujudnya perlindungan hukum untuk setiap orang dengan memperhatikan unsur kepastian hukum, kemanfaatan, dan keadilan. Keberlakuan sanksi terhadap perbuatan melawan hukum yang merugikan masyarakat pen ting diterapkan guna memastikan peraturan tidak dilanggar. Peraturan yang dikeluarkan pemerintah terkait covid-19 salah satunya adalah Keppres No. 11/2020 tentang Kedaruratan Kesehatan Masyarakat sebagai bentuk peringatan kepada masyarakat akan bahaya virus Corona yang tengah melanda hampir seluruh dunia. Diperlukan kerjasama yang baik dari berbagai pihak dalam upaya penanggulangan wabah ini diantaranya dengan berlaku jujur dalam memberikan keterangan mengenai kesehatannya kepada tenaga kesehatan agar pengobatan dapat dilakukan secara cepat dan tepat. Kejujuran akan menyelamatkan banyak nyawa termasuk nyawa tenaga kesehatan yang sedang bertugas menangani pasien terinfeksi covid-19. Ketidakjujuran dalam memberikan 
informasi kondisi kesehatan tergolong tindakan menghalangi penanggulangan wabah berdasarkan Pasal 14 ayat (1) dan (2) UU No. 4 tahun 1984 tentang Kekarantinaan Kesehatan. Selain iru, ancaman pidana diberikan kepada seseorang yang lalai hingga rnengakibatkan seseorang meninggal dunia dinyatakan dalam pasal 359 KUHP.

Demi mengurangi tingginya indeks kematian tenaga kesehatan selama pandemi virus corona, pemerintah berupaya memberikan perlindungan kepada tenaga kesehatan yang bertujuan menciptakan rasa aman melalui perlindungan preventif rnaupun perlindungan represif. Perlindungan hukum preventif ditujukan kepada tenaga kesehatan melalui pemenuhan kebutuhan selama bertugas seperti pemberian jarninan berupa penyediaan Alat Pelindung Diri (APD), pemberian vitamin dan makanan kepada tenaga kesehatan merupakan upaya pemerintah melindungi garda depan penanganan covid-19. Ketika seluruh upaya preventiftelah dilakukan namun terjadi pelanggaran ataupun sengketa, maka upaya perlindungan represif dilakukan melalui penerapan sanksi hukum bagi pelanggar aturan hukum.

\section{Saran}

Berdasarkan simpulan di atas maka dapat dikemukakan beberapa saran sebagai berikut:

a. Kepada Pemerintah. Ketentuan pidana tidak menyebutkan secara spesifik kondisi jika pasien berbohong, namun penafsiran mengenai orang yang tidak jujur bisa dikategorikan menghalanghalangi penanggulangan wabah, perlu mendapatkan penjelasan secara spesifik agar tidak menimbulkan pro dan kontra ataupun multitafsir sehingga sanksi yang diberikan dapat memenuhi unsur kepastian hukum, kemanfaatan, dan keadilan.

b. Kepada masyarakat. Diperlukan kesadaran dan kerjasama yang baik antara masyarakat dengan pemerintah dalam penanggulangan wabah penyakit menular, Salah satunya adalah dengan memberikan informasi yang jujur mengenai kondisi kesehatannya kepada tenaga kesehatan sebagai bentuk kewajiban yang harus dilaksanakan.

\section{DAFTAR PUSTAKA}

Asshiddiqie, J. (2007). Hukum Tata Negara Darurat. Jakarta: Raja Grafindo Persada.

Asyiah, N. (2016). Perlindungan Hukum Warga Negara terhadap Tindakan Pemerintah dalam Membuat Keputusan Administrasi Negara. Jurnal Hukum Samudra Keadilan, 11(1), 44-54.

Aurelia, B. (2017). Penanggulangan Penyakit Menular. Malang: Bayumedia Publishing.

Fajar, M., \& Yulianto, A. (2009). Dualisme Penelitian Hukum Normatif. Yogyakarta: Pustaka Pelajar.

Komalawati, V. (2002). Peranan Informed Consent dalam Transaksi Teraupetik. Bandung: Citra Aditya Bakti.

Lamintang, P. A. F. (2010). Delik-delik khusus: Kejahatan terhadap Nyawa, Tubuh \& Kesehatan. Jakarta: Sinar Grafika.

Mertokusumo, S. (1999). Mengenal Hukum. Yogyakarta: Liberty.

Pesulima, T. L., \& Hetharie, Y. (2020). Perlindungan Hukum terhadap Keselamatan Kerja Bagi Tenaga Kesehatan Akibat Pandemi Covid-19. SASI, 26(2), 280-285.

Purbacaraka, P., \& Soekanto, S. (1979). Sendi-Sendi Ilmu Hukum dan Tata Hukum. Bandung: Alumni.

Sukendar, \& Santoso, A. P. A. (2019). Tindak Pidana dalam Praktik Keperawatan Mandiri (Perlindungan Hukum bagi Perawat dan Pasien). Yogyakarta: Nuha Medika. 